\title{
Revisión
}

\section{Bornavirus y enfermedades neuropsiquiátricas}

Xinia Barrantes-Rodríguez', Sandra Silva-de la Fuente', José A. Bonilla-Vargas', Fernando I. Puerto².

Resumen

La enfermedad producida por el virus de la enfermedad de Borna (VEB) o Borna Disease Virus (BDV), conocida como una encefalitis fatal, se ha reportado en caballos y ovejas en Europa Central, desde hace más de dos siglos. Los animales infectados por el VEB muestran cambios en el comportamiento: ansiedad, agresividad, separación del rebaño e hiperactividad. Estos signos también pueden encontrarse en seres humanos, con trastornos psiquiátricos como: enfermedad bipolar, depresión, esquizofrenia o encefatilis idiopáticas. Estas manifestaciones en los animales infectados se deben, principalmente, a la respuesta inmune contra las células infectadas del sistema nervioso central (SNC).

Desde 1980 se ha demostrado evidencia serológica de infección por el VEB en humanos. Sin embargo, aún existe mucho por investigar en este tema. En numerosos estudios se ha intentado asociar la presencia de anticuerpos o de partículas virales con manifestaciones psiquiátricas.

Debido a que los desórdenes psiquiátricos son un problema importante en salud pública, y a que la gran mayoría de los reportes científicos se han hecho en países desarrollados en donde la epidemiología de las enfermedades muestra un comportamiento muy distinto a la que se observa en países tropicales en vías de desarrollo, es necesario realizar análisis rigurosos para corroborar o refutar el efecto de la infección por el VEB en algunas enfermedades mentales.

Descriptores: Bornavirus, esquizofrenia, enfermedad bipolar, VEB.

Key words: Borna Disease Virus, schizophrenia, bipolar disease, BDV.

Recibido: 25 de octubre de 2005

Aceptado: 28 de marzo de 2006

Muchos agentes patógenos tienen tropismo por el SNC, causan desórdenes neurológicos o estados mentales anormales. Sin embargo, solo VEB se ha asociado con disfunciones en el desarrollo de las estructuras cerebrales ${ }^{1}$. Estudios del comportamiento en animales infectados con VEB sugieren también una asociación en humanos con desórdenes psiquiátricos ${ }^{2}$.

\section{Características del virus}

El VEB es un virus envuelto, no lítico, con ARN de cadena negativa y no segmentado (NNS) ${ }^{3}$. Es el único miembro de la familia Bornaviridae del orden de los Mononegavirales, que también incluye las familias Filoviridae, Paramyxoviridae y Rhabdoviridae. Tiene una morfología esférica con un diámetro de 70 a $130 \mathrm{~nm}$. Posee un núcleo interno denso $(50-60 \mathrm{~nm})$ y una membrana externa con espículas de aproximadamente $7 \mathrm{~nm}$ de longitud ${ }^{4-10}$.

La infectividad viral se reduce rápidamente a $56^{\circ} \mathrm{C}$, a pH menor de 5 o mayor de 12 , y con detergentes, solventes orgánicos, formaldehído y radiación ultravioleta. 
Se conocen cuatro cepas: Borna V, Borna HE/80, Borna No/98 y Borna H1766. Los genomas han sido secuenciados y la homología entre secuencias es del $80 \%$ al $98 \%{ }^{10}$.

La infección causa desórdenes neurológicos en caballos, ovejas y otros animales de granja en Europa Central. En ratas, que son probablemente los animales más susceptibles, el virus puede replicarse en otros tipos de células del SNC, incluyendo astrocitos. Las células neuronales de varias especies son susceptibles a la infección in vitro. Los síntomas neurológicos son el resultado de la respuesta inmune en contra de las células del SNC infectadas persistentemente. Dependiendo de la respuesta inmune y de la cinética de la replicación viral, una infección persistente puede originar una enfermedad neuronal severa ${ }^{3}$.

Experimentalmente, VEB infecta además aves y primates no humanos; se ha reportado en varios animales silvestres; los períodos de incubación y los síntomas son variables ${ }^{5-7}$.

\section{Organización genómica y proteínas estructurales}

El genoma del VEB ( 8.9 kb) es característico de los Mononegavirales. Posee seis marcos de lectura abiertos (ORF). Estos ORFs codifican polipéptidos de 40 (p40), 24 (p24), 10 (p10), 16 (p16), 56 (p56) y 180 (p180) kDa. De acuerdo con sus posiciones en el genoma viral, su abundancia en las células infectadas, sus características bioquímicas y su secuencia, los polipéptidos del VEB p40, p24 y p16 corresponden a la nucleoproteína viral $(\mathrm{N})$, la fosfoproteína (P) activadora transcripcional, y proteínas de matriz (M), respectivamente ${ }^{5,11,12}$. Se han identificado además 3 intrones: el I de $2.5 \mathrm{~kb}$, el II de $7.2 \mathrm{~kb}$ y el III de $8.4 \mathrm{~kb}^{13}$.

\section{Ciclo de reconocimiento y replicación del VEB}

La entrada del VEB a la célula se da por endocitosis mediada por receptor ${ }^{4,14}$. Los anticuerpos antiproteína $G$ (glicoporteína de superficie p56) tienen actividad neutralizante, lo que sugiere que esta proteína está implicada en la adsorción, penetración, o ambos ${ }^{4,15}$. Evidencia reciente indica que la región $\mathrm{N}$ terminal de p56 es suficiente para el reconocimiento del receptor y la entrada del virus ${ }^{4,16}$. El N terminal de gp43 contiene un dominio hidrofóbico, y las células infectadas forman un extenso sincitio a $\mathrm{pH}$ básicos; esto sugiere que gp43 está involucrada en la fusión pHdependiente después de la internalización. La fusión libera la RNP, la cual es transportada al núcleo de la célula, donde ocurre la transcripción y la replicación ${ }^{4,17}$.

El ARNm sufre edición con baja eficiencia y los polipéptidos que se generan, con excepción de $\mathrm{N}$, son traducidos de ARNm policistrónicos, característica única de los Mononegavirus. La complejidad del ciclo del VEB requiere una variedad de eventos de transporte núcleo-citoplasma de las macromoléculas virales ${ }^{4}$. La transcripción del ARNr ocurre en el nucleolo ${ }^{18}$.

\section{Patogénesis}

\section{Neuroinvasión y neuropropagación}

La evidencia sugiere que la ruta primaria de infección es nasal, a través del neuroepitelio olfatatorio. Después de la replicación inicial en las neuronas localizadas en el sitio de entrada VEB migra intra-axonal al SNC. En ratas inoculadas el VEB se replica en el neuroreceptor del epitelio olfatorio ${ }^{4,5}$.

En el núcleo de las neuronas infectadas, los agregados de material viral forman cuerpos de inclusión de JoestDegen, característicos de la infección por VEB. Las partículas maduras no se detectan durante la propagación en SNC, lo que sugiere que lo hacen en forma de ribonucleoproteínas. La infección afecta algunos neurotransmisores. Su distribución en el hipocampo coincide con algunos aminoácidos de receptores excitatorios como el glutamato.

En el sistema nervioso periférico se pueden detectar agentes virales y ARN en astrocitos, oligodendrocitos ${ }^{19}$, células ependimales, y células de Schwann. En infecciones avanzadas, el virus difunde en forma radial, posiblemente al utilizar el transporte axonal anterogrado. El virus se ha detectado en nervios periféricos de todos los tejidos y órganos. Los anticuerpos neutralizantes pueden aparecer durante la infección y se han relacionado con restricción de la replicación viral en el sistema nervioso central ${ }^{46,20}$.

\section{Neuropatogénesis}

La enfermedad causada por VEB se define como una encefalomielitis no purulenta, debida al mecanismo inmune dependiente de linfocitos $\mathrm{T}$. Ratas infectadas experimentalmente desarrollan un comportamiento bifásico mediado por respuesta inmune. La alta expresión génica en el sistema límbico, junto a las alteraciones en los astrocitos y estructuras neuronales dentro del hipocampo, definen la histopatología de la enfermedad. La extensa reacción inflamatoria (30 a 40 días después de la infección) lleva a una destrucción neuronal que puede desencadenar en hidrocefalia. Linfocitos $\mathrm{T} \mathrm{CD}^{+}$y CD$^{+}$están presentes en infiltrados del SNC y su eliminación o bloqueo puede prevenir los síntomas y los cambios histopatológicos ${ }^{4,5,21}$.

En ratas, el infiltrado inicial en los espacios perivasculares está compuesto de células $\mathrm{T} \mathrm{CD}^{+}, \mathrm{CD} 4^{+}, \mathrm{NK}$ y macrófagos ${ }^{2,22}$. Linfocitos de cerebros de ratas con infección aguda, expresan un MHC-I restringido a linfocitos T citotóxicos. La especificidad citolítica de células T CD8 ${ }^{+}$ está dirigida hacia el epítopo de la nucleoproteína viral p40 ${ }^{4,23-25}$.

Los cambios en el comportamiento asociados al VEB, pueden deberse a alteraciones del sistema dopaminérgico, como disminución de receptores D2 y D3. Además, se han descrito otras alteraciones, como cambios en niveles de ARNm de colecistokinina, ácido glutámico descarboxilasa, 
y somatostatina que pueden ser consecuencia de la respuesta inflamatoria.

Aumento en interleucinas: IL-6, TNF- $\alpha$, IL-1 $\alpha$ y óxido nítrico sintasa ARNm inducible en cerebros de rata infectados, correlacionan con el grado de inflamación y severidad $^{4,26}$.

Animales que sobreviven muestran signos de una enfermedad crónica, con resolución de los infiltrados inflamatorios del SNC. Las ratas Lewis que sobreviven muestran destrucción permanente del cerebro (ej. hidrocefalia) y signos crónicos de enfermedad neurológica (como apatía, y ceguera) ${ }^{2}$.

A pesar de que el virus se distribuye en el cerebro, la neuropatología se concentra en el girus dentate, cerebelo y neocorteza, donde las células granulares, células de Purkinje y células piramidales sufren apoptosis. Aunque se da respuesta inmune, su distribución no correlaciona con el sitio dañado. La neuropatología colocaliza con proliferación de microglia y expresión de MHC clase I y II, ICAM, CD4 y CD8, lo que sugiere que la patología está relacionada con activación de la microglia y apoptosis de poblaciones neuronales específicas, más que por el tropismo viral o la respuesta inmune específica ${ }^{27}$.

\section{Epidemiología}

\section{Reservorios}

Debido a que es posible infectar ratas, ratones, ovejas y caballos en forma experimental, vía intranasal, se puede asumir que la infección puede ocurrir por esta ruta, sin embargo, la vía natural de infección aún no se ha determinado. La infección puede cursar asintomática en animales de granja. La ausencia de mutaciones específicas de especie en el VEB entre animales de granja, está en favor de que estos animales sirven de reservorios. El factor geográfico, la frecuencia del virus en establos con poca higiene y la periodicidad estacional, podrían sugerir la existencia de un roedor como reservorio. Ratas recién nacidas infectadas, que no desarrollan enfermedad neurológica, excretan el virus en orina y posiblemente en otras secreciones ${ }^{28}$.

Se ha detectado infección natural en caballos, perros, ovejas, ganado vacuno, conejos, cabras, ciervos, alpacas, llamas, gatos, linces, hipopótamos, perezosos, monos Vari (Memur variegatus) y avestruces ${ }^{5,6}$.

\section{Infecciones en humanos}

Las infecciones en humanos pueden cursar sin fiebre, sin cambios mentales o signos típicos de encefalitis, pero podrían inducir signos psiquiátricos como: depresión, manía, ansiedad, desórdenes cognoscitivos, disquinesia tardía, disfunción social, desórdenes auditivos y enfermedades idiopáticas. Si ocurre en los tres primeros años de vida, puede ocasionar autismo, ansiedad crónica, déficits cognoscitivos y desarrollo anormal del cerebelo y del hipocampo ${ }^{2}$.

Ensayos con inmunofluorescencia (IFA) muestran en el suero de algunos pacientes psiquiátricos, IgG específica para antígenos de VEB. Estos anticuerpos son menos frecuentes en controles sanos, lo que sugiere asociación del VEB con desórdenes psiquiátricos ${ }^{5}$.

Se han encontrado niveles anormales de BDNF (factor neurotrófico derivado de cerebro) y receptores 5-HT (serotonina), así como reducción del número de formaciones sinápticas en cerebros de personas con desórdenes mentales. Ratones transgénicos desarrollan desórdenes neuropatológicos y anormalidades neurofisiológicas similares a los descritos en humanos, y el daño en la función de las células gliales puede ser un factor común para la inducción de desordenes de comportamiento ${ }^{20}$.

En diferentes estudios serológicos, se observó que la prevalencia de anticuerpos anti-VEB en pacientes psiquiátricos, varía del $0 \%$ al $30 \%$. Esto puede deberse a los diferentes métodos de detección ${ }^{29,30}$. Por ejemplo, en Yucatán, México, se encontró una prevalencia del $21.43 \%$ en pacientes esquizofrénicos y del $0 \%$ en pacientes sanos ${ }^{31}$.

Los cuadros 1 y 2 muestran algunos ejemplos de prevalencias obtenidas en varios estudios; se observa una mayor prevalencia en pacientes con enfermedades psiquiátricas.

\section{Diagnóstico}

Entre las pruebas más utilizadas para el dianóstico de la infección por VEB están:

A. Detección de anticuerpos anti-VEB: La inmunoflorescencia indirecta (IFI) es rápida y sensible para ser utilizada para muestras de diferentes animales, sin embargo, en humanos, no es suficientemente específica. Los "inmunoblots" son más específicos que la IFI, pero poco sensibles. Los ELISAS tienen una sensibilidad mayor y han sido más utilizados.

B. Pruebas inmunológicas para detección de proteínas virales: Para detectar proteínas en tejidos se ha usado la inmunohistoquímica post mortem, también se ha reportado el uso de citometría de flujo en sangre periférica $^{2,36}$.

C. Detección de ácidos nucléicos virales: El RT-PCR detecta el virus circulante en células monononucleares de sangre periférica, también se ha usado el RT-PCR anidado y RT-PCR Tiempo Real ${ }^{2,32,33}$. El aislamiento del virus mediante cultivo celular es poco usado, es costoso y de difícil estandarización ${ }^{2,37}$.

EL RT-PCR tiempo real permite la cuantificación continua de los productos de PCR mediante el uso de oligonucleótidos marcados ${ }^{38}$. Es específico, rápido, reproducible y muy sensible, lo cual permite detectar pocas copias del 


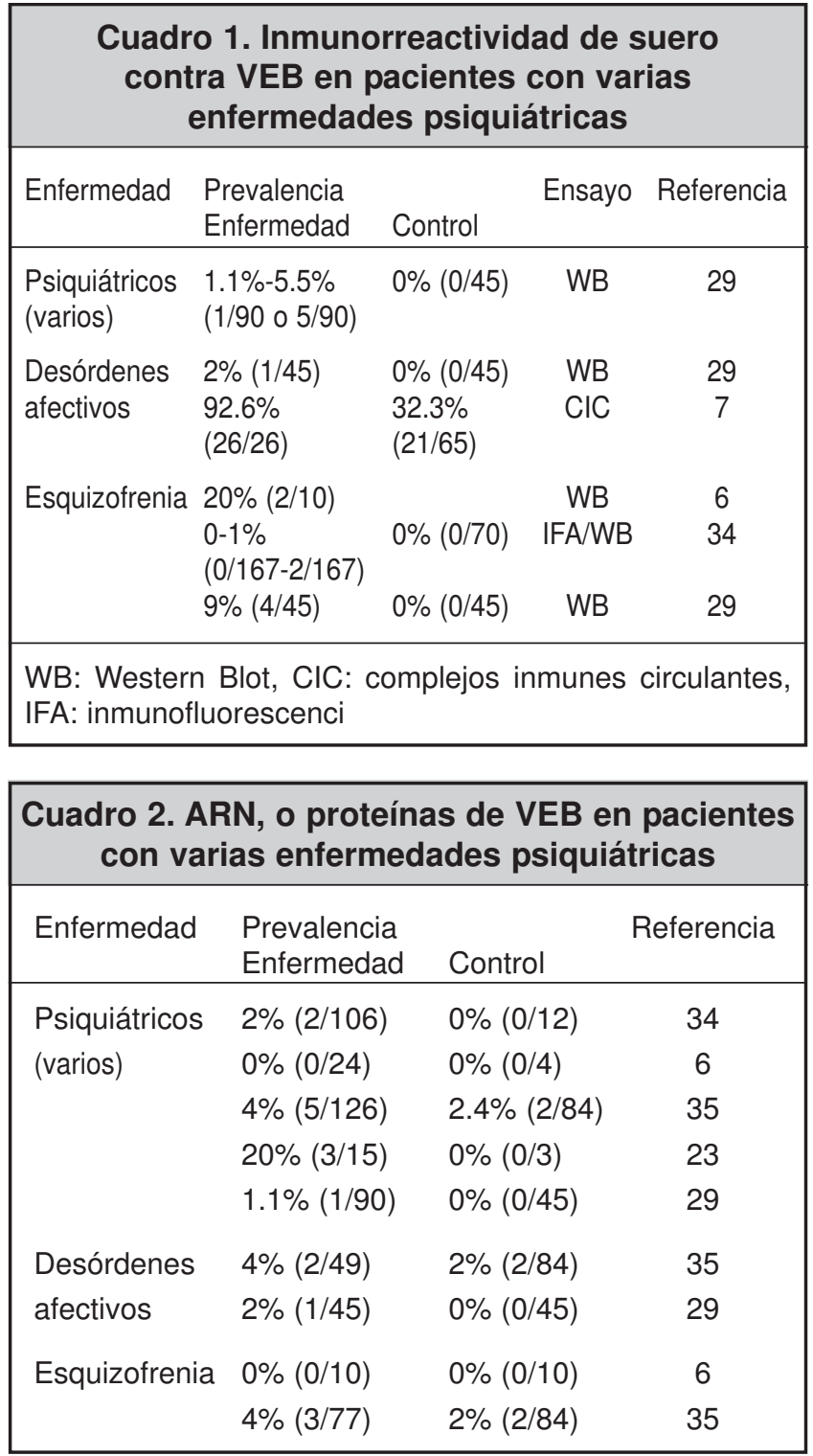

virus. Schindler, 2004, utilizó esta técnica para detección y cuantificación de VEB en hospederos enfermos y en garrapatas inoculadas experimentalmente, con excelentes resultados, logró detectar hasta una molécula por reacción ${ }^{10}$.

\section{Tratamiento}

La inmunidad pasiva en ratas aún no ha mostrado controlar o prevenir la infección. La vacunación a partir de cultivos de alto título viral puede proteger parcialmente. La transferencia de linfocitos $\mathrm{T}$ específicos contra el virus, al inicio de la infección, reduce la infección. Otros reportan que la amantidina es efectiva ${ }^{2}$ y la ribavirina intracerebral causa mejora clínica en ratas ${ }^{39}$.

El análogo nucleósido 1- $\beta$-D-arabinofuranosilcotisina (Ara-C), un inhibidor de la ADN polimerasa, inhibe la replicación viral, la síntesis de proteínas, previene la infección célula-célula, inhibe la replicación in vivo en cerebro y previene la persistencia de la infección en ratas ${ }^{40}$.
Además, se observó que los anticuerpos antiglicoproteína mayor (gp94) pueden prevenir la enfermedad. Esto puede ser un importante hallazgo para la formulación de una vacunas ${ }^{41}$. Stiz et al. demostraron que se puede prevenir la infección generalizada con anticuerpos neutralizantes ${ }^{42}$.

Actualmente muchos desórdenes psiquiátricos se describen como "síndromes"; en conclusión, se puede decir que el VEB podría ser solo un cofactor en el desarrollo de la enfermedad. La prevalencia de anticuerpos o fragmentos genómicos del VEB en la población sana puede sugerir que el virus tiene una baja patogenicidad, sin embargo, la prevalencia aumenta en pacientes con desorden depresivo mayor y desorden bipolar, lo que sugiere asociación entre la infección viral y la enfermedad.

La prevalencia del VEB varía de un estudio a otro, probablemente debido a la falta de consenso en los protocolos de laboratorio, a la aparente baja afinidad de las inmunoglobulinas humanas contra los antígenos virales, y a la baja cantidad de virus circulantes en sangre.

La alta prevalencia de enfermedades mentales en Costa Rica demanda hacer un estudio adecuado, que nos permita conocer la incidencia de infección y estimar el impacto en enfermedades mentales. El Centro de Investigación en Biología Celular y Molecular de la Universidad de Costa Rica ha iniciado una investigación para detectar ácidos nucléicos virales que codifican las proteínas p24 y 40 en plasmas de pacientes psiquiátricos. Se empleará el RT-PCR tiempo real, por su sensibilidad y especificidad para obtener resultados certeros.

\section{Abstract}

The disease caused by Borna Disease Virus (BDV), known as fatal encephalitis, has been diagnosed in horses and sheeps en Central Europe for over a century. Infected animals show changes in the behaviour such as anxiety, separation of the herd, and hyperactivity. This signs can be found in humans with psychiatric syndromes like bipolar disease, depression, schizophrenia, or idiopathic diseases. The manifestations in infected animals are due to the immune response against the infected cells in the central nervous system.

Since 1980, serological evidence of BDV infection has been reported in humans and many suggested an association of specific antibodies or viral particles with psychiatric manifestations.

Because most of the studies have been done in developed countries where epidemiological manifestations are different to those observed in tropical developing countries, it is necessary to do rigorous analysis to corroborate or refute the effect of BDV in some mental diseases. 


\section{Referencias}

Bode L, Ludwig H. Borna disease virus infection, a human mental-health risk. Clin Microbiol Rev 2003; 16: 534-545.

2. Carbone K. Borna disease virus and human disease. Clin Microbiol Rev 2001; 14: 513-527.

3. Staeheli P, Sauder C, Hausmann J, Ehrensperger F, Schwemmle M Epidemiology of Borna disease virus. J Gen Virol 2000; 81: 2123-2135.

4. De la Torre J. Bornavirus and the brain. J Infect Dis 2002; 186: S241S247.

5. Hornig M, Briese T, Lipkin W. Borna disease virus. J NeuroVirol 2003; 9:259-273.

6. Richt J, Pfeuffer I, Christ M, Frese K, Bechter K, Herzog S. Borna disease virus infection in animals and humans. Emerg Infect Dis 1997; 3 343-352.

Bode L, Reckwald P, Severus W, Stoyloff R, Ferszt R, Dietrich D, et al. Borna disease virus-specific circulating immune complexes, antigenemia, and free antibodies-the key marker triplet determinating infection and prevailing in severe mood disorders. Mol Psyquiatr 2001; 6:481-491.

8. Pérez M, Sánchez A, Cubitt B, Rosario D \& de la Torre J. A reverse genetics system for Borna disease virus. J Gen Virol 2003 ; 84:30993104.

9. Kohno T, Goto T, Takasaki T, Morita C, Nakaya T, Ikuta K, et al. M. Fine structure and morphogenesis of Borna disease virus. J Virol 1999; 73 760-766.

10. Schilder, A. 2004. Real Time RT-PCR for tracing and quantification of Borna disease virus RNA in diseased hosts compared to experimentally inoculate ticks. Tesis de doctorado, Universidad de Suiza, Suiza. 53 p.

11. Schneider P, Hatalski C, Lewis A, Lipkin I. Biochemical and functional analysis of the Borna disease virus G protein. J Virol 1997; 71: 331-336

12. Kraus I, Eickmann M, Kiermayer S, Scheffczik H, Fluess M, Richt J, et al. Open Reading Frame III of Borna Disease Virus Encodes a Nonglycosylated Matrix Protein. J Virol 2001; 75: 12098-12104.

13. Cubitt B, Ly C \& de la Torre J. Identification and characterization of a new intron in Borna disease virus. J Gen Virol 2001; 82: 641-646.

14. González-Dunia D, Cubitt B, de la Torre J. Mechanism of Borna disease virus entry into cells. J Virol 1998; 72: 783-788.

15. Bajramovic J, Syan S, Brahic M, de la Torre J, Gonzalez D.1-ß-D-arabinofuranosylcytosine inhibits Borna disease virus replication and spread. J Virol 2002; 76: 6268-6276

16. González-Dunia D, Cubitt B, Grasser F, de la Torre J. Characterization of Borna disease virus p56 protein, a surface glycoprotein involved in virus entry. J Virol 1997; 71: 3208-3218

17. Walker MP, Lipkin W. Characterization of the nuclear localization signal of the Borna disease virus polymerase. J Virol 2002; 76: 8460-8467.

18. Pyper P, Clements J, Zink M. The nucleolus is the site of Borna disease virus RNA transcription and replication. J Virol 1998; 72: 7697-7702.

19. Ibrahim M, Watanabe M, Palacios A, Kamitani W, Komoto S, Kobayashi $\mathrm{T}$, et al. Varied persistent life cycles of Borna disease virus in a human oligodendroglioma cell line. J Virol 2002; 76: 3873-3880

20. Kamitani W, Ono E, Yoshino S, Kobayashi T, Taharaguchi S, Lee B, et al. Glial expression of Borna disease virus phosphoprotein induces behavioral and neurological abnormalities in transgenic mice. Proc Natl Acad Sci U S A 2003;100: 8969-8974.

21. Lewis A, Whitton L, Hatalski C, Weissenböck H, Lipkin W. Effect of immune priming on Borna disease. J Virol 1999; 73: 2541-2546.

22. Hashimoto Y, Chen H, Cunningham C, Malik T, Lai P. Two major histocompatibility complex class I-restricted epitopes of the Borna disease virus p10 protein identified by cytotoxic $\mathrm{T}$ lymphocytes induced by DNA-based immunization. J Virol 2003; 77: 6076-6081.
23. Planz O, Stitz L. Borna disease virus nucleoprotein (p40) is a major target for CD8+-T-cell-mediated immune response. J Virol 1999; 73: 17151718 .

24. Hausmann J, Schamel K, Staeheli P. CD8+ T lymphocytes mediate Borna disease virus-induced immunopathology independently of perforin. J Virol 2001; 75: 10460-10466.

25. Hausmann J, Hallensleben W, de la Torre J, Pagenstecher A, Zimmermann M, Pircher H, et al. T cell ignorance in mice to Borna disease virus can be overcome by peripheral expression of the viral nucleoprotein. Proc Natl Sci 1999; 96: 9769-9774.

26. Sobbe M, Bilzer T, Gommel S, Noske K, Planz O, Stitz L. Induction of degenerative brain lesions after adoptive transfer of brain lynphocytes from Borna disease virus-infected rats: presence of CD8+ T cells and perforin M RNA. J Virol 1997; 71: 2400-2407.

27. Weissenbock H, Horning M, Hickey W, Lipkin W. Microglial activation and neuronal apoptosis in Bornavirus infected neonatal Lewis rats. Brain Pathol 2000;10:260-272.

28. Staeheli P, Sentandreu M, Pagenstecher A, Hausmann J. Alpha/beta interferon promotes transcription and inhibits replication of Borna disease virus in persistently infected cells. J Virol 2001; 75:8216-8223.

29. Fukuda K, Takahashi K, Iwata Y, Mori N, Gonda K. Immunological and PCR analyses for Borna disease virus in psychiatric patients and blood donors in Japan. J Clin Microbiol 2001; 39: 419-429.

30. Terayama H, Nishino Y, Kishi M, Ikuta K, Itoh M, Iwahashi K. Detection of anti-Borna disease virus (BDV) antibodies from patients with schizophrenia and mood disorders in Japan. Psychiatr Res 2003; 120: 201-206.

31. Puerto F, Zavala J, Rosado A, Gamboa J. Serological survey of Borna disease virus in schizophrenec patients from Yucatán, México. Rev Biomed 2004; 15:141-147.

32. Nowotny N, Kolodziejek, Jehle C, Suchy A, Staeheli P, Schwemmle M. Isolation and Characterization of a New Subtype of Borna Disease Virus. J Virol 2000; 74:5655-5658.

33. Fujiwara S, Takahashi H, Nakaya T, Nakamura Y, Nakamura K, Iwahashi $\mathrm{K}$, et al. Microplate hybridization for Bona disease virus RNA in human peripheral blood mononuclear cells. Clin Diagn Lab Inmunol 1997; 4: 387-391.

34. Kubo K, Fujiyoshi T, Tokoyama M, Kamel K, Richt J, Kitze B, et al. Lack of association of Borna disease virus and human T-cell leukemia virus type 1 infections with psychiatric disorders among Japanese patients. Clin Diagn Lab Inmunol 1997; 4: 189-194.

35. Iwata Y, Takahashi K, Peng X, Fukuda K, Ohno K, Ogawa T et al. Detection and sequence analysis of Borna disease virus p24 RNA from peripheral blood mononuclear cells of patients with mood disorders or schizophrenia and of blood donors. J Virol 1998; 72: 10044-10049.

36. Cotto E, Neau D, Cransac-Neau M, Auriacombe M, Pellegrin J, Ragnaud $\mathrm{J}$, et al. Borna disease virus RNA in inmunocompromised patients in Southwestern France. J Clin Microbiol 2003; 41: 5577-5581.

37. Nakamura Y, Takahashi H, Shoya Y, Nakaya T, Watanabe M, Tomonaga $\mathrm{K}$, et al. Isolation of Borna disease virus from human brain tissue. J Virol 2000; 74: 4601-4611.

38. Radonic A, Thulke S, Mackay I, Landt O, Siegert W, Nitsche A. Guideline to reference gene selection for quantitative real-time PCR. Biochem Biophys Res Comm 2004; 13: 856-862.

39. Solbrig M, Schlaberg R, Briese T, Horscroft N, \& Lipkin W. Neuroprotection and reduced proliferation of microglia in ribavirin-treated Bornavirus-infected rats. Antimicrob Agents Chemother 2002; 46: 2287-2291

40. Bajramovic J, Münter S, Syan S, Nehrbass U, Brahic M, Gonzalez-Dunia D. Borna disease virus glycoprotein is required for viral dissemination in neurons. J Virol 2003; 77: 12222-12231.

41. Furrer E, Bilzer T, Stitz L, Planz O. Neutralizing antibodies in persistent Borna disease virus infection: prophylactic effect of gp94-specific monoclonal antibodies in preventing encephalitis. J Virol 2001; 75: 943-951.

42. Stitz L, Nöske K, Planz O, Furrer E, Lipkin W, Bilzer T. A functional role for neutralizing antibodies in Borna disease: Influence on virus tropism outside the central nervous system. J Virol 1998; 72: 8884-8892. 